\title{
Hydraulic activities by ghost shrimp Neotrypaea californiensis induce oxic-anoxic oscillations in sediments
}

\author{
N. Volkenborn ${ }^{1, *, * *}$, L. Polerecky ${ }^{2, * *}$, D. S. Wethey ${ }^{1}$, T. H. DeWitt ${ }^{3}$, S. A. Woodin ${ }^{1}$ \\ ${ }^{1}$ Department of Biological Sciences, University of South Carolina, 715 Sumter Street, Columbia, South Carolina 29208, USA \\ ${ }^{2}$ Max Planck Institute for Marine Microbiology, Celsiusstraße 1, 28359 Bremen, Germany \\ ${ }^{3}$ Pacific Coastal Ecology Branch, Western Ecology Division, US Environmental Protection Agency, Newport, Oregon 97365, USA
}

\begin{abstract}
Porewater pressure sensing, time-lapse photography, and planar optode imaging of oxygen were applied to investigate hydraulic activities by thalassinidean ghost shrimp Neotrypaea californiensis and the associated dynamics of oxygen in and around their burrows. Ghost shrimp were hydraulically active $40 \%$ of the time. For $>90 \%$ of this time the sediment was pressurized, which caused transport of oxygenated water into the burrow and the surrounding sediment, and transport of anoxic water through the sediment-water interface. Sediment blow-outs and irrigation episodes with the shrimp in head-down orientation caused flow reversals and porewater transport towards the burrow. At sediment permeabilities $>2 \times 10^{-13} \mathrm{~m}^{2}$ these porewater pressure dynamics were detected throughout the entire sediment volume within the shrimp tanks (6 l) even if a second burrow opening was established. Intermittent burrow irrigation performed at different locales within the burrow was sufficient to maintain oxic conditions during $>90 \%$ of the time in burrow parts frequented by the shrimp. In contrast, sediment surrounding the burrows and surficial sediment were characterized by irregular oxygen supply, with oxic and anoxic conditions alternating on the time-scale of 1 to 1.5 times $\mathrm{h}^{-1}$. The oscillatory regions around the burrows were restricted to a few millimeters in muddy sediments, but extended up to $4 \mathrm{~cm}$ away from the burrow in more permeable sediments. The oscillatory character of porewater chemistry in the presence of hydraulically active organisms is expected to have significant effects on microbial diversity and biogeochemical processes in marine sediments.
\end{abstract}

KEY WORDS: Bioturbation - Bioirrigation - Bioadvection - Redox oscillations · Oxygen dynamics · Infaunal behavior $\cdot$ Burrowing $\cdot$ Thalassinidea $\cdot$ Neotrypaea californiensis

Resale or republication not permitted without written consent of the publisher

\section{INTRODUCTION}

Bioturbation is a key process affecting the functioning of benthic systems (Aller 1982, Kristensen 2001, Welsh 2003). Besides displacing sediment particles, benthic organisms enhance solute exchange across the sediment-water interface by flushing their burrows with the overlying water for respiratory or feeding purposes (Riisgård \& Larsen 2005). The delivery of high energy electron acceptors, such as oxygen, associated with bioirrigation affects rates of biogeochemical processes in the sediment surrounding animal burrows (Aller 1988, Kristensen \& Kostka 2005, Laverock et al. 2011). Without bioirrigating infauna and topography-driven interfacial water flows (Huettel et al. 1996) the transport of porewater constituents is governed by diffusion, and organic mineralization by microbes occurs in a vertically stratified manner that follows the sequence of energy yields from available electron acceptors $\left(\mathrm{O}_{2}>\mathrm{NO}_{3}{ }^{-}>\mathrm{MnO}>\mathrm{Fe}(\mathrm{III})>\right.$ 
$\mathrm{SO}_{4}{ }^{2-}>\mathrm{CO}_{2 i}$ Aller 1982). Infaunal activities perturb the stratified distribution of metabolites, and, due to the inherent differences in chemical constituents of the overlying water and porewater, bioirrigation creates a distinct functional environment with unique geochemical properties (Aller 1994) and highly heterogeneous distributions of microbial assemblages (Papaspyrou et al. 2005, Bertics \& Ziebis 2009, Laverock et al. 2010). The mosaic of spatially and temporally complex and dynamic geochemical conditions is expected to be a challenging environment for obligate aerobic and anaerobic bacteria, with the relative duration of oxic and anoxic periods being a crucial determinant of microbial activity (Aller 1994, CravoLaureau et al. 2011). However, our knowledge of the spatial extent and temporal characteristics of such oscillatory zones in sediments is still limited.

The spatial scale of impact strongly depends on the burrow morphology and the sediment type. In the case of organisms with blind-ending burrows and without extensive burrow linings (e.g. arenicolid polychaetes), burrow ventilation induces substantial advective water flow in sandy sediments (Meysman et al. 2005, Wethey et al. 2008), while porewater advection is thought to be negligible in muddy sediments with high resistance to interstitial water flow, especially if 2 or more burrow openings are established (Foster-Smith 1978, Aller 1988, MermillodBlondin \& Rosenberg 2006). In contrast to extreme situations (blind-ending burrow in sand vs. U-shaped burrow in mud) the significance of porewater advection around infaunal burrows in intermediate situations, e.g. more complex burrows with open and blind ending parts, in sediments of intermediate permeability is less well understood.

The temporal dynamics of geochemical conditions within and potentially around burrows are directly linked to infaunal activity. Ventilation typically occurs intermittently (Forster \& Graf 1995, Kristensen 2001, Volkenborn et al. 2010), and interstitial flow of water is driven by behavior-specific porewater pressure gradients, i.e. bioadvection caused by hydraulic activity (Wethey et al. 2008, Volkenborn et al. 2010, Woodin et al. 2010). Furthermore, recent studies indicate bidirectional water flow away and towards the animal or into and out of the burrow (Volkenborn et al. 2010, Kristensen et al. 2011, Quintana et al. 2011) . Intermittency and bidirectionality of irrigation implies very dynamic geochemical conditions, but a quantitative characterization of this oscillatory environment on spatial and temporal scales appropriate to link the geochemical dynamics to infaunal activity has not been done in detail.
In the present work, we used the thalassinidean ghost shrimp Neotrypaea californiensis as a model organism to study quantitatively the oscillatory conditions in sediments related to hydraulic activity of bioirrigating macrofauna that maintain complex burrow structures. Thalassinid crustaceans are considered to be amongst the most important bioturbating infaunal organisms in marine sediments (Atkinson \& Taylor 2005, Pillay \& Branch 2011). They maintain and irrigate complex, deep-reaching burrow structures that significantly affect the structure and functioning of benthic systems (Posey 1986, Ziebis et al. 1996, D'Andrea \& DeWitt 2009). Numerous studies on burrow morphology (Griffis \& Chavez 1988, Rowden \& Jones 1995, Coelho et al. 2000) and thalassinidean behavior (Dworschak 1981, Stamhuis et al. 1996, Astall et al.1997) emphasized the large plasticity of these parameters amongst species, individuals of the same species, as well as amongst sediment types (reviewed by Atkinson \& Taylor 2005). The ghost shrimp $N$. californiensis is a deposit-feeding representative of this group that is abundant in a wide range of sediment types in intertidal areas along the western coast of North America from Alaska to Mexico (MacGinitie 1934, DeWitt et al. 2004). It maintains complex burrow structures in soft sediments that can be $>1 \mathrm{~m}$ deep, typically with 1 or 2 openings and without a substantial burrow lining (Griffis \& Suchanek 1991, Dumbauld et al. 1996).

To identify hydraulically effective behaviors of Neotrypaea californiensis, their frequencies and the scale of their geochemical impact, we used real-time porewater pressure records and time-lapse photography in combination with planar optode oxygen imaging. We conducted our experiments in sediments ranging from highly permeable sand to sandy mud to better understand the animal-sediment interaction across the wide range of environments inhabited by this species. This is the first attempt to measure the spatial patterns of oxygen dynamics synchronously in different parts of thalassinid burrows, link these dynamics to shrimp behaviors, and quantitatively characterize the oscillatory conditions within and around complex burrow structures.

\section{MATERIALS AND METHODS}

\section{Shrimp tank set-up}

Measurements were conducted in transparent aquaria (internal dimensions $50 \times 5 \times 57 \mathrm{~cm}$ ) constructed from $1.25 \mathrm{~cm}$ thick acrylic plates. Oxygen 
sensitive foils (optodes; Precht et al. 2004) were glued onto separate plates $(50 \times 1.8 \times 50$ and $50 \times 1.8 \times$ $7 \mathrm{~cm}$ ) using a double-sided tape (x-Film). In each tank, the plates with the optodes facing the interior of the tank were inserted along one of the original aquarium walls and held in position with a U-shaped piece of closed cell foam (Monster Funnoodle, Jakks Pacific). The cell foam was squeezed between the optode plate and the distal tank wall $3.2 \mathrm{~cm}$ away to prevent penetration of fine particles between the transparent side of the optode plate and the tank wall. On both sides of the tank, a PVC U-channel bar $(2.2 \times 2.5 \times 45 \mathrm{~cm})$ holding an array of 4 embedded pressure probes was inserted, which allowed continuous recording of porewater pressures at sediment depths of approximately 5, 15, 25, and $35 \mathrm{~cm}$. With the optode plate, cell foam sealing, and pressure sensor bars in place, the sediment volume available for the shrimp was approximately $40 \times 3 \times 50 \mathrm{~cm}^{3}$.

Sediments were collected at 2 different intertidal locations in Yaquina Bay, Oregon (sandy mud and muddy sand), and at 1 intertidal location in Alsea Bay, Oregon (sand). Hereafter, we refer to these sediment types as M (sandy mud), MS (muddy sand), and $\mathrm{S}$ (sand). Surficial (top $2 \mathrm{~cm}$, brownish) and subsurface sediment ( 2 to $20 \mathrm{~cm}$, black) were sampled separately and sieved through a $2 \mathrm{~mm}$ mesh to remove larger organisms and particles. The homogenized subsurface and surface sediment was dribbled into the tanks to resemble the vertical sediment stratification in the field. During this procedure tanks were first filled with seawater to avoid trapping of air bubbles in the sediment. Subsequently, the turbid overlying water was replaced with clear seawater to avoid formation of a fine particle layer at the sediment surface. After settling, the thicknesses of the subsurface and surficial sediment layers were 44 to 48 and $2 \mathrm{~cm}$, respectively. Fresh seawater from a reservoir was pumped above the sediment surface at a rate of $120 \mathrm{ml} \mathrm{min}^{-1}$, resulting in a complete exchange of the overlying water approximately once in every $10 \mathrm{~min}$. Oxygen concentration in the overlying water of the aquaria varied between 70 to $100 \%$ air saturation, which is sufficient to support active shrimp (Thompson \& Pritchard 1969).

The sediment sampling and shrimp tank set-up procedure may have altered the sediment characteristics compared to the undisturbed in situ conditions, but we are confident that these sediments represented the range of sediment types inhabited by Neotrypaea californiensis. Of these 3 sediment types, the MS sediment represents closest the sediment type where the highest population densities of $N$. californiensis are found in the field (>150 shrimp $\mathrm{m}^{-2}$; T. DeWitt unpubl. data), whereas $\mathrm{M}$ and $\mathrm{S}$ sediments represented approximately the distributional limits of this species with respect to granularity and the physical environment (Dumbauld et al. 1996, DeWitt et al. 2004).

\section{Experimental procedure}

Parallel measurements were performed in 2 tanks simultaneously. The first 3 experimental runs included $1 \mathrm{M}$ and $1 \mathrm{MS}$ set-up, the fourth run was done with $2 \mathrm{~S}$ set-ups. Large Neotrypaea californiensis specimens, which were egg-carrying females at the time of this study, were collected from the muddy site at Yaquina Bay, Oregon. One individual per tank was added 18 to $24 \mathrm{~h}$ after the tanks had been filled with sediment. Each experimental run started on the day when the tanks were filled with sediment and lasted for $5 d_{i}$ thus, the experimental period included $1 \mathrm{~d}$ of data acquisition without shrimp and $4 \mathrm{~d}$ with shrimp.

At the end of each experimental run, volumetric sedimentary oxygen consumption rates (OCR) were determined by carefully injecting $10 \mathrm{ml}$ of $100 \%$ airsaturated water into the sediment close to the optode at 3 to 6 different locations a few centimeters away from shrimp burrows and 10 to $20 \mathrm{~cm}$ below the sediment surface. The initial rate of decrease in the porewater oxygen concentrations was calculated in every optode image pixel where oxygen was detected (between 25 and 325 pixels, covering an area of 10 to $140 \mathrm{~mm}^{2}$ ). Subsequently, these rates were multiplied by sediment porosity to express the OCR values per unit volume of sediment (Polerecky et al. 2005, Volkenborn et al. 2010). Finally, the OCR values in all pixels for each injection locale were averaged, and the averages for all locations were used to calculate the mean and standard deviation of OCR for each tank.

In parallel with the set-up of each shrimp tank, 3 replicate sediment cores were prepared identically. These cores (area: $10 \mathrm{~cm}^{2}$, depth: 10 to $15 \mathrm{~cm}$ ) were used for the measurement of permeability by the constant head method (Klute \& Dirksen 1986). Two subsamples from each core (approximately $4 \mathrm{ml}$ of sediment), taken with cut-off syringes at 3 to $6 \mathrm{~cm}$ depth, were then used to determine organic content (by loss on ignition) and porosity (by weight loss after drying).

\section{Oxygen imaging}

Oxygen distributions inside the sediments were measured with the luminescence lifetime imaging 
system described by Matsui et al. (2011). In the present set-up, images were acquired at $30 \mathrm{~s}$ intervals, covered both shrimp tanks, and had an effective pixel size of $0.44 \mathrm{~mm}^{2}$. Optodes were calibrated using the lifetime values measured in the anoxic sediment and in the air-saturated overlying water.

\section{Time-lapse photography}

Images of the shrimp tanks were taken with digital SLR cameras (Nikon D200) triggered by time-lapse controllers (Digi-Snap, Harbortronics). Images were taken at 15 to $30 \mathrm{~s}$ intervals, and the effective pixel size ranged between 0.07 and $0.09 \mathrm{~mm}^{2}$.

\section{Porewater pressure measurements}

The differential pressure sensors used in the present study (Honeywell 27PC) are piezoresistive bridges that provide a differential voltage proportional to the pressure difference between the 2 sides of the sensor. While one side of the sensor was in direct contact with the sediment porewater (gage pressure), the ambient (hydrostatic) pressure was detected within a water-filled space within the PVC channels (plenum) that was in direct contact with the overlying water and isolated from the porewater. Data were collected at $200 \mathrm{~Hz}$ using autonomous 8-channel 16-bit data loggers (Persistor CF2). Amplifiers on the boards allowed adjustment of the dynamic range of the sensors. Sensors were calibrated by varying the water heights on both sides of the sensors, i.e. the plenum and sediment side. Twelve positive and negative pressures were applied to each sensor, and the linear calibration between the gauge pressure and measured voltage had $\mathrm{R}^{2}>0.95$.

\section{Data analysis}

Burrow morphologies were reconstructed based on the combined information from time-lapse photographs and oxygen images. Characterization of shrimp activity and the related porewater pressure waveforms was done by visual inspection of the timelapse photographs and of the synchronous pressure records. Time-series of porewater pressure data were analyzed with respect to the durations and frequencies of hydraulically important behaviors. Two subsequent irrigation events were interpreted as individual bouts if the porewater pressure between them reached zero for longer than $1 \mathrm{~s}$. Ninety-seven percent of all intervals between subsequent bouts were longer than $5 \mathrm{~s}$.

Sedimentary oxygen dynamics induced by shrimp activity were characterized by a number of parameters derived from the oxygen time-series. First, sediment oxygenation for each image pixel and time point was classified as oxic or anoxic if the $\mathrm{O}_{2}$ concentration fell above or below a threshold value, respectively. To minimize the influence of noise in the $\mathrm{O}_{2}$ images, the threshold value of $5 \%$ air saturation was used. Subsequently, durations of oxic $\left(T_{\mathrm{OX}}\right)$ and anoxic $\left(T_{\mathrm{ANOX}}\right)$ periods were calculated from these time-series as intervals when the oxygenation status remained oxic and anoxic, respectively. For each pixel the temporal means and standard deviations were calculated. The frequency of oxic-anoxic oscillations $\left(F_{\mathrm{OSC}}\right)$ was determined by counting complete transitions from oxic to anoxic and back to oxic conditions divided by the total duration of the $\mathrm{O}_{2}$ image time-series ( $T_{\text {TOTAL }}$ ). The average oxygenation probability $\left(\mathrm{Pr}_{\mathrm{O} 2}\right)$ was calculated by dividing the total duration of the oxic periods by $T_{\text {TотAL }}$. The average oxygen concentration during oxic conditions $\left(c_{\mathrm{OXX}}\right)$ was determined by averaging oxygen concentrations over all oxic periods. Linear profiles over 7 adjacent pixels (approximately $5 \mathrm{~mm}$ wide) were extracted to visualize spatial correlations between the parameters.

\section{RESULTS}

\section{Sediment characteristics}

Permeability differed by almost 3 orders of magnitude between the 'muddiest' sediment in the M tanks and the most permeable sandy sediment in the $\mathrm{S}$ tanks (Table 1). Sedimentary oxygen consumption rates also covered a wide range, with rates about 70- and 30-fold higher in M and MS sediments than in the $\mathrm{S}$ sediment, respectively. The porosity did not vary appreciably among the sediment types, and organic matter content varied only by a factor of 2 to 3 (Table 1). The intermediate MS sediment, which resembled the 'typical' shrimp habitat, had a permeability of $1 \times 10^{-11} \mathrm{~m}^{2}$, a porosity of $40 \%$, and an organic content of $0.8 \%$. While the MS and $\mathrm{S}$ replicates had very comparable sediment characteristics, the $\mathrm{M}$ replicates were much more variable (Table 1), reflecting the large spatial variability of sediment characteristics on the scale of meters for this habitat. 
Table 1. Characteristics of the sediments (M: sandy mud; MS: muddy sand; S: sand) in experimental tanks and of the morphology of burrows established by Neotrypaea californiensis after 4 to $5 \mathrm{~d}$ of incubation. $k$ : sediment permeability; K: hydraulic conductivity; OCR: oxygen consumption rate per volume of sediment; TOM: total organic carbon; shrimp size: carapace length measured according to Dumbauld et al. (1996)

\begin{tabular}{|c|c|c|c|c|c|c|c|c|c|c|c|}
\hline Tank & $\begin{array}{c}k \\
\left(10^{-12} \mathrm{~m}^{2}\right)\end{array}$ & $\begin{array}{c}K \\
\left(\mathrm{~cm} \mathrm{~min} \min ^{-1}\right)\end{array}$ & $\begin{array}{r}\mathrm{O} \\
(\mu \mathrm{mol} \\
\text { Mean }\end{array}$ & $\left.h^{-1}\right)$ & $\begin{array}{l}\text { Porosity } \\
\text { (vol. \%) }\end{array}$ & $\begin{array}{l}\text { TOM } \\
\text { (wt \%) }\end{array}$ & $\begin{array}{c}\text { Incubation } \\
\text { time (h) }\end{array}$ & $\begin{array}{l}\text { Shrimp } \\
\text { size }\end{array}$ & $\begin{array}{l}\text { Burrow } \\
\text { depth }\end{array}$ & $\begin{array}{l}\text { Burrow } \\
\text { length }\end{array}$ & Turning \\
\hline M1 & 0.7 & 0.035 & 3.1 & 2.0 & 45 & 1.03 & 95 & 13.4 & 13.8 & 55.7 & 7 \\
\hline M2 & 0.04 & 0.0021 & 4.4 & 0.6 & 52 & 2.22 & 121 & 13.5 & 20.6 & 48.1 & 6 \\
\hline M3 & 0.2 & 0.0084 & 2.2 & 0.3 & 52 & 1.61 & 123 & 13.6 & 11.3 & 41.3 & 5 \\
\hline MS1 & 10.6 & 0.54 & 1.6 & 0.1 & 42 & 0.79 & 95 & 12.3 & 29.5 & 44.3 & 6 \\
\hline MS2 & 9.7 & 0.55 & 1.5 & 0.2 & 43 & 0.78 & 119 & 13.8 & 16.2 & 66.3 & 9 \\
\hline MS3 & 9.7 & 0.54 & 1.3 & 0.2 & 44 & 0.88 & 122 & 13.3 & 32.1 & 82.3 & 8 \\
\hline $\mathrm{S} 1$ & 32.7 & 1.54 & 0.05 & 0.02 & 43 & 0.68 & 112 & 13.3 & 39.2 & 68.7 & 9 \\
\hline S2 & 33.8 & 1.59 & 0.03 & 0.01 & 42 & 0.62 & 117 & 13.4 & 30.4 & 38.1 & 3 \\
\hline
\end{tabular}

\section{Burrow morphology}

All shrimp individuals started burrowing into the sediment immediately after they were added to the aquaria. Excavated sediment was brought up to the sediment surface, which resulted in continuous growth of a sand mound above the burrow opening. If a second burrow opening was established, this was also frequently used for burrow tailings. A representative time-lapse video of burrow establishment over a $90 \mathrm{~h}$ incubation interval can be found in Supplement 2 (Video S1; available at www.int-res.com/ articles/suppl/m455p141_supp/).

After $4 \mathrm{~d}$, the burrows were morphologically diverse, ranging from single oblique tunnels with only 1 opening to U- and Y-shaped burrows typically with 2 openings (Fig. 1). In the $\mathrm{M}$ sediment, the shrimp typically started with the establishment of a

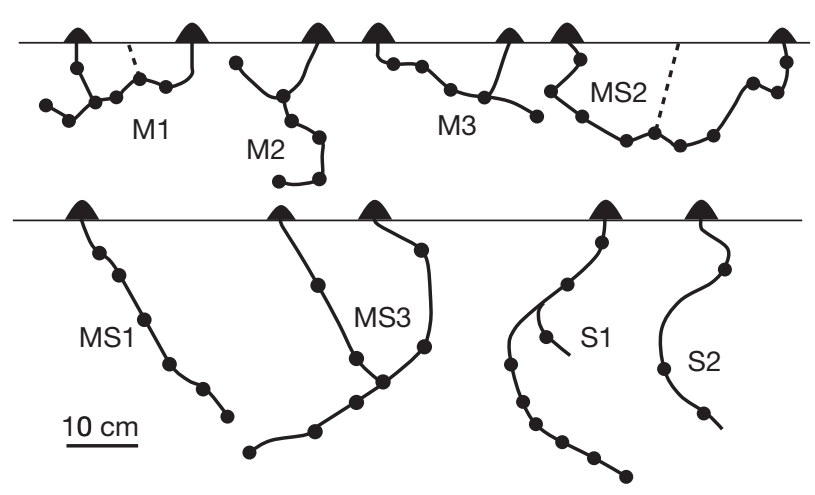

Fig. 1. Neotrypaea californiensis. Diversity of burrow morphology after 4 to $5 \mathrm{~d}$ of burrowing by ghost shrimp in narrow aquaria. Large and small humps indicate sediment excavation mounds. Dotted lines: ephemeral burrow structures; filled circles: turning chambers. Letter abbreviations in Table 1. Establishment of burrow MS2 can be seen in the time-lapse Video S1 in Supplement 2 at www.int-res.com/ articles/suppl/m455p141_supp/ relatively shallow U-shaped burrow (approximately $10 \mathrm{~cm}$ deep), with the $\mathrm{U}$ widening over the course of the experiment due to the establishment of new vertical burrow shaft connections to the overlying water and the collapse of old ones. In the S sediment, both individuals established deep, blind-ending burrows with only 1 opening. In the MS sediment, both burrowing practices were observed. There was a positive trend of the maximal burrow depth with sediment permeability $\left(R^{2}=0.61, p=0.02\right)$. Based on the combined information from time-lapse photographs and oxygen images, the 'average' burrow penetrated to a depth of $24 \mathrm{~cm}$, was $57 \mathrm{~cm}$ long (including side branches), and had 7 dilations (turning chambers) that were 5 to $10 \mathrm{~cm}$ apart (Table 1 ).

\section{Behavior-specific porewater pressure waveforms}

Hydraulic activities by the shrimp caused dynamic porewater pressurizations and the pressure waveforms were behavior specific (Fig. 2). Porewater pressure plateaus mostly above and sometimes below the hydrostatic baseline were detected during burrow irrigation achieved by pleopod beating while the shrimp was positioned in a narrow part of the burrow (Fig. 2A,D,F; Video S2 in Supplement 2). The mean frequency of pleopod beats was $22 \pm 4 \mathrm{~min}^{-1}$ $( \pm \mathrm{SD}, \mathrm{n}=8$, with $>20$ irrigation bouts analyzed per individual), as derived from the small pressure oscillations superimposed on the pressure plateaus during the irrigation bouts (Fig. 2K). Pleopod beat frequencies were significantly lower for individuals in the $\mathrm{M}$ sediments $\left(17 \pm 1 \mathrm{~min}^{-1} ; \mathrm{n}=3\right)$ compared to those in the $\mathrm{S}$ and MS sediments $\left(25 \pm 1 \mathrm{~min}^{-1} ; \mathrm{n}=6\right.$; $F_{2,5}=48.31 ; \mathrm{p}<0.001$; Tukey post hoc $\mathrm{p}<0.05$ ). Elevated pressure plateaus were detected when the 


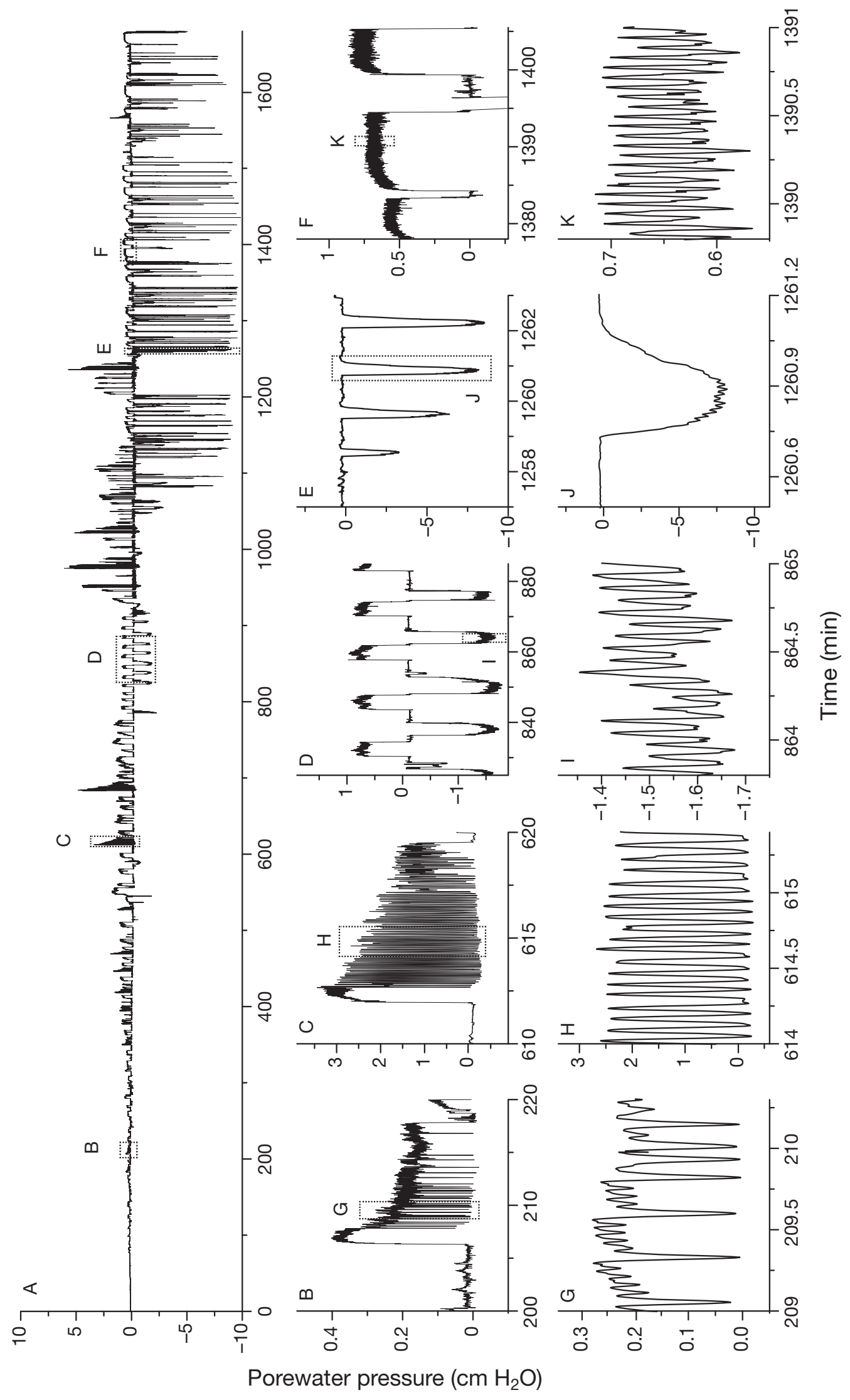

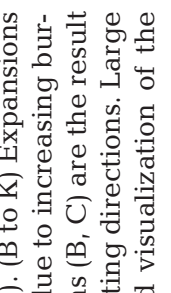

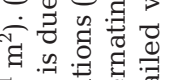

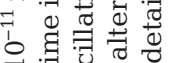

$\vec{x}$ 至声

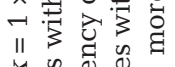

$\forall$ a 000

要专

है

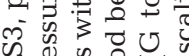

$\sum_{1}^{2}$ है ?

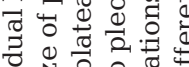

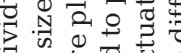

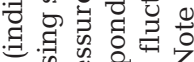

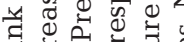

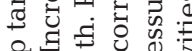

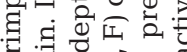

क

o

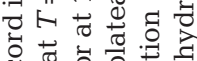

o 00

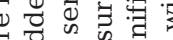

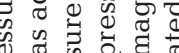

, 3 过

屯ै 워

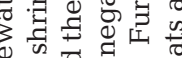

웅 면

a

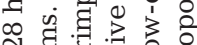

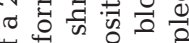

पे

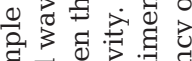

สี ซٓ

过 气 :

进过

जै

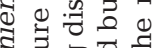

政 8

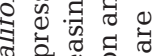

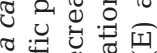

讨

क.

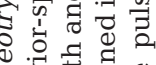

之.

(a)

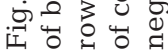


animal pumped water into the burrow, while reduced pressure plateaus were detected when irrigation direction was reversed (Fig. 2D). For most of the irrigation bouts the amplitude of the individual oscillations was small $(<10 \%$ of the mean plateau pressurization above or below hydrostatic baseline), while for some oscillations the amplitude spanned the entire interval between hydrostatic baseline and the maximum pressurization (Fig. 2C,H). Some of the pressure plateaus contained both large- and smallmagnitude pressure oscillations alternating periodically (Fig. 2B,G). The large-magnitude oscillations were often associated with burrow excavation, and were most likely the result of combined burrowing, feeding, and irrigation activity. Large but short (5 to $25 \mathrm{~s})$ negative pressure waveforms were associated with sediment blow-outs (Fig. 2A,E, J; Video S3 in Supplement 2), as confirmed by time-lapse photography. These large negative pressure transients were induced by high-frequency pleopod beats with an individual average frequency ranging from 77 to $95 \mathrm{~min}^{-1}$ (Fig. 2J). Movements of the shrimp along the burrow did not cause detectable pressurization of the sediment and were thus not classified as a hydraulic activity.

\section{Durations and frequencies of hydraulic activities}

Time allocation for different hydraulic activities varied considerably among Neotrypaea californiensis individuals (Table 2), but there were no apparent behavioral differences with sediment type or time in the aquaria. Using pressure records obtained for 8 individuals over 25 to $49 \mathrm{~h}$ on Days 3 and 4 of the experimental runs, we estimated the average durations and frequencies of the hydraulically effective behaviors. The shrimp were hydraulically active during $40 \pm 10 \%$ (SD among individuals) of the time. The pressure records were characterized by positive pressurization during $37 \pm 12 \%$ of the time and negative pressurization during $3.1 \pm 2.2 \%$ of the time. The most frequent hydraulic activity $(34 \pm 12 \%$ of the time) was burrow irrigation by pleopod beating, with $8.8 \pm 2.0$ irrigation bouts $\mathrm{h}^{-1}$, of which $7.4 \pm 2.4$ lasted longer than $1 \mathrm{~min}$. The average duration of an irrigation bout was $2.4 \pm 1.1 \mathrm{~min}$, and the interval between 2 successive irrigation bouts was $4.7 \pm 1.2 \mathrm{~min}$. The longest irrigation bout per individual lasted $21.0 \pm$ $10.4 \mathrm{~min}$. The pressure records, as well as time-lapse photography, indicated periods of pronounced burrow excavation activity that lasted 35 min on average. Such burrow excavation periods occurred on average $4.1 \pm 2.4$ times per $24 \mathrm{~h}$, and each of these periods was characterized by $9.7 \pm 4.6$ sediment blow-outs with an average duration of $13.7 \pm 4.0 \mathrm{~s}$ separated by $3.4 \pm 0.7 \mathrm{~min}$. The blow-outs accounted for $0.4 \pm 0.5 \%$ of the time budget.

\section{Bioadvection associated with hydraulic activities}

The magnitudes and shapes of the biohydraulically induced porewater pressure fields during burrow irrigation depended on the permeability of the sediment as well as on the distances between the pressure sensor, the shrimp burrow, and the actual location of an active shrimp (Supplement 1a at www.int-res.com/ articles/suppl/m455p141_supp.pdf). In the sediment with the lowest permeability $\left(<10^{-13} \mathrm{~m}^{2}\right)$, porewater pressure magnitudes detected in close proximity to the

Table 2. Neotrypaea californiensis. Time allocations of hydraulically effective behaviors and temporal characteristics of burrow irrigation by pleopod beating. Values are shown for 3 sediment types (M: sandy mud; MS: muddy sand; S: sand), and are based on the analysis of porewater pressure time-series over 25 to $49 \mathrm{~h}$. Overall: percentage of the observation period with hydraulically effective behaviors; intervals: time periods between bouts

\begin{tabular}{|c|c|c|c|c|c|c|c|c|c|c|c|c|c|}
\hline \multirow{3}{*}{ Tank } & \multirow{3}{*}{$\begin{array}{c}\text { Time } \\
\text { analyzed } \\
\text { (h) }\end{array}$} & \multirow{3}{*}{$\begin{array}{c}\text { Overall } \\
(\%)\end{array}$} & \multicolumn{2}{|c|}{ Time allocation } & \multirow{3}{*}{$\begin{array}{c}\text { Bouts } \\
\left(\mathrm{h}^{-1}\right)\end{array}$} & \multirow{2}{*}{\multicolumn{6}{|c|}{$\begin{array}{cc}\text { Irrigation by pleopod beating } \\
\text { Duration (min) } & \text { Beats }\left(\min ^{-1}\right)\end{array}$}} & \multirow{2}{*}{\multicolumn{2}{|c|}{ Intervals (min) }} \\
\hline & & & Positive & Negative & & & & & & & & & \\
\hline & & & $\begin{array}{l}\text { pressuri- } \\
\text { zation }(\%)\end{array}$ & $\begin{array}{l}\text { pressuri- } \\
\text { zation }(\%)\end{array}$ & & Mean & $\mathrm{SD}$ & Median & Max. & Mean & $\mathrm{SD}$ & Mean & $\mathrm{SD}$ \\
\hline M1 & 46 & 47.1 & 45.8 & 1.3 & 11.4 & 2.2 & 2.1 & 1.7 & 19.9 & 18 & 5 & 3.1 & 4.9 \\
\hline M2 & 38 & 41.2 & 40.7 & 0.5 & 12.0 & 1.6 & 1.8 & 1.0 & 14.5 & 16 & 3 & 3.7 & 6.4 \\
\hline M3 & 25 & 48.9 & 47.9 & 0.9 & 6.5 & 4.3 & 4.3 & 2.5 & 19.6 & 18 & 4 & 4.9 & 8.4 \\
\hline MS1 & 46 & 35.7 & 31.1 & 4.6 & 7.9 & 2.2 & 2.7 & 1.7 & 24.7 & 25 & 7 & 5.4 & 8.2 \\
\hline MS2 & 49 & 21.5 & 16.7 & 4.8 & 7.4 & 1.4 & 1.3 & 1.0 & 7.9 & 23 & 6 & 6.7 & 9.4 \\
\hline MS3 & 47 & 38.7 & 33.2 & 5.4 & 9.2 & 2.0 & 2.0 & 1.3 & 12.0 & 26 & 4 & 4.4 & 6.4 \\
\hline S1 & 40 & 31.5 & 25.8 & 5.7 & 8.5 & 1.6 & 2.2 & 1.1 & 29.1 & 26 & 4 & 5.5 & 9.3 \\
\hline $\mathrm{S} 2$ & 45 & 55.3 & 53.6 & 1.6 & 7.8 & 4.0 & 5.0 & 2.7 & 40.5 & 25 & 5 & 3.7 & 3.6 \\
\hline
\end{tabular}


active shrimp within its burrow were large but steeply declined with distance, reaching $<1 \%$ at the opposite side of the tank (Fig. S1 in Supplement 1a). In contrast, for permeabilities $\geq 2 \times 10^{-13} \mathrm{~m}^{2}$, significant porewater pressurization was detected simultaneously on all 8 sensors (Fig. S1 in Supplement 1a), demonstrating that the hydraulic forces, and thus porewater flow, pervaded the entire sediment in the shrimp tanks ( 61 of sediment containing 2.71 of porewater). This was true even if more than 1 burrow opening existed (Fig. 3).

The perfusing nature of bioadvection was further confirmed by the dynamically varying position of the
Blind-ending burrow (18 $\mathrm{h}$ after shrimp addition)
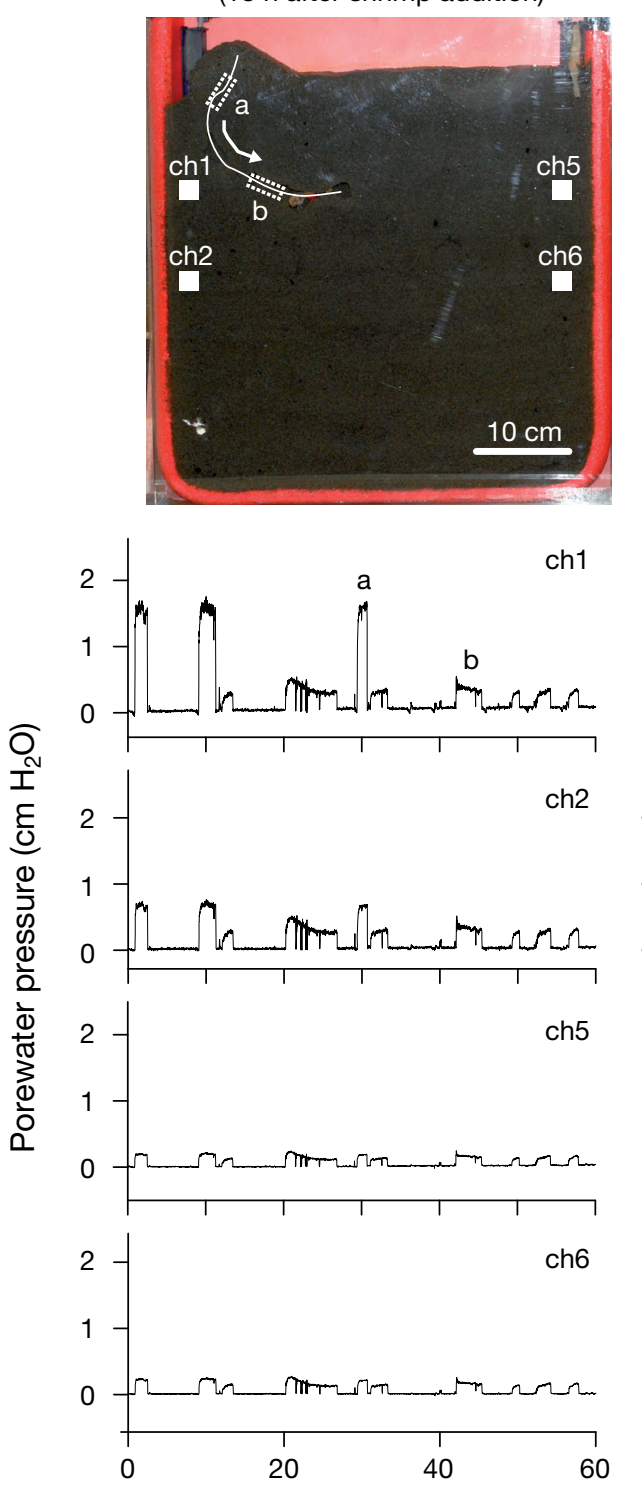

Burrow with 2 openings (83.5 $\mathrm{h}$ after shrimp addition)
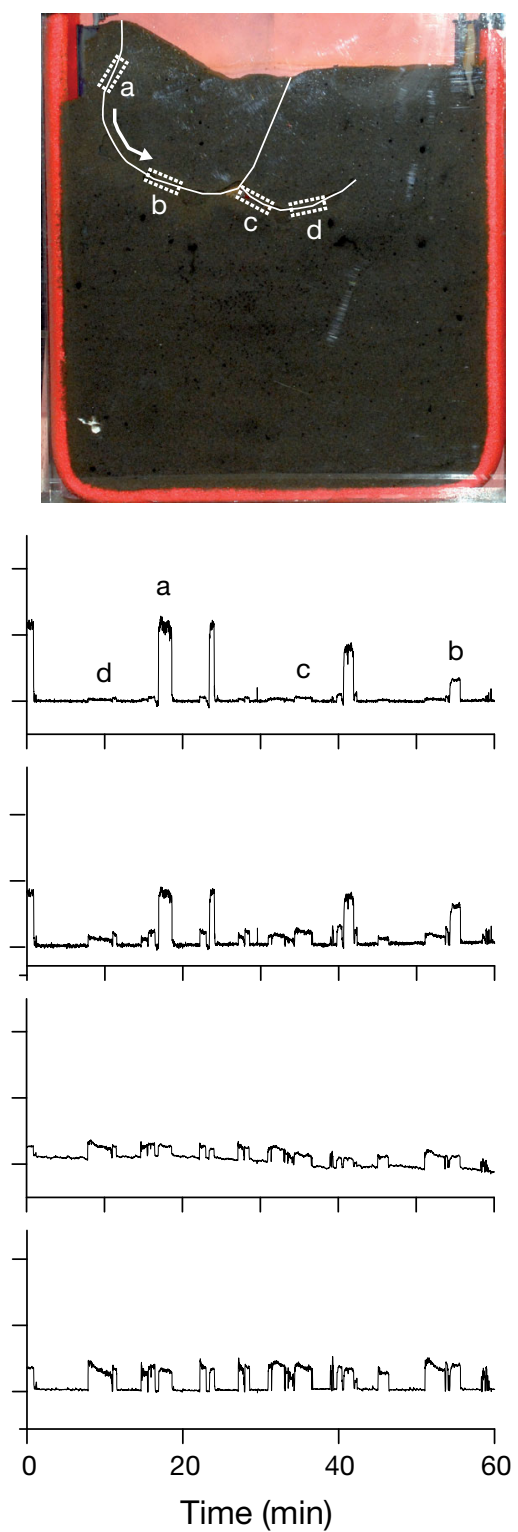

Burrow with 3 openings (98 $\mathrm{h}$ after shrimp addition)
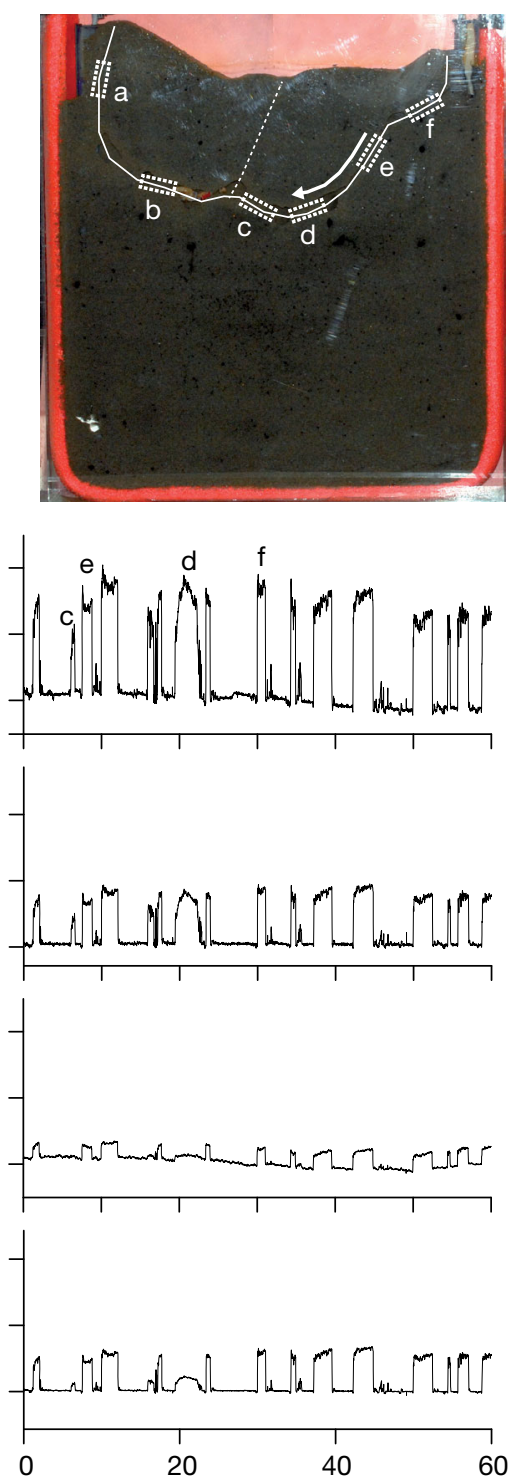

Fig. 3. Neotrypaea californiensis. Porewater pressure dynamics induced by ghost shrimp during irrigation of a burrow of increasing size and complexity. Shown are $60 \mathrm{~min}$ pressure records detected simultaneously at depths of 15 and $25 \mathrm{~cm}$ on both sides of a shrimp tank (ch: pressure sensor). The left panels represent a blind-ending burrow. After $83.5 \mathrm{~h}$ (centre panels) the shrimp had established an ephemeral second vertical connection to the overlying water. After $98 \mathrm{~h}$ (right panels) an open burrow had been established, and both openings were used for sediment blow-outs. Small letters in the pressure records (a to f) indicate pressure waveforms that correspond to irrigation at different locales (white dotted boxes in the photographs). Note that the predominant flow direction, indicated by white arrows, was reversed after $98 \mathrm{~h}$ as suggested by time-lapse images. A time-lapse video of the establishment of this burrow can be found in Supplement 2 (Video S1) at www.int-res.com/articles/suppl/m455p141_supp/ 
oxic-anoxic boundaries surrounding the anoxic sediment. When the sediment was pressurized, the outward movement of the oxic-anoxic boundary at the sediment-water interface as well as at the location of the incomplete vertical sealing demonstrated that anoxic porewater was forced out of the sediment (Fig. 4; Video S4 in Supplement 2, available at www. int-res.com/articles/suppl/m455p141_supp/). In contrast, the opposite movement of the oxic-anoxic boundary demonstrated drawing of oxygenated water into the sediment during negative pressurization. The oxic- anoxic boundary at the sediment surface typically moved upwards with velocities of 0.1 to $0.7 \mathrm{~cm} \mathrm{~min}{ }^{-1}$.

\section{Oxygen dynamics in the burrow lumen and sediment surrounding the burrow}

Images derived from the oxygen time-series illustrated a number of general characteristics of the oxy-

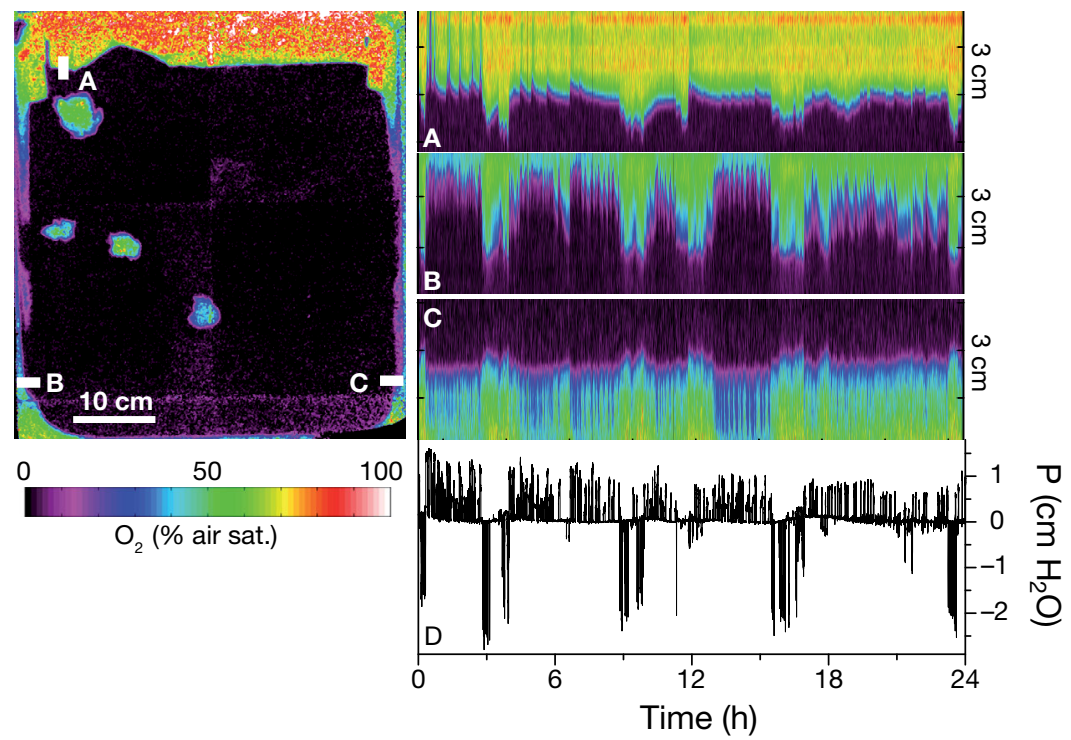

Fig. 4. Neotrypaea californiensis. Movement of oxic-anoxic boundaries associated with the porewater flow induced by hydraulic activities of ghost shrimp (individual MS3; permeability $k=10^{-11} \mathrm{~m}^{2}$ ). Positions of the vertical profile across the sediment-water interface and of the horizontal profiles across the semi-permeable seal along the lateral walls of the tanks are shown in the example $\mathrm{O}_{2}$ image on the left. The corresponding $\mathrm{O}_{2}$ dynamics along these profiles are plotted in Panels A to C. Note that, due to the profile orientation, away from the sediment is up in Panels A and B but down in Panel C. The corresponding synchronous porewater pressure record, with positive and negative sediment pressurization episodes, is shown in Panel D. Porewater pressurization during periods of pleopod irrigation moved porewater away from the burrow, out through the sediment surface, and through the vertical sealing on the aquarium sides. During burrow excavation episodes with repeated sediment blow-outs, negative pressurization caused porewater flow reversal and water was drawn towards the burrow and into the surficial sediment. The corresponding timeseries of oxygen distributions can be found in Supplement 2 (Video S4) gen dynamics induced by the hydraulic activities of Neotrypaea californiensis (Figs. 5 \& 6). Oxygen probability profiles through the shrimp burrow always in the center of the oscillatory regions (green lines: Fig. 6J-L). Zones where oxygen probability exceeded $75 \%$ and the frequency of oxic-anoxic oscillations (red filled areas: Fig. 6K-L) was $\ll<\mathrm{h}^{-1}$ corresponded to areas where the burrow lumen was in close proximity to, or in direct contact with, the oxygen optode (Fig. 5A,B). Average oxygen concentram455p141_supp.pdf).

In contrast to the mostly oxic conditions in parts of temporally variable oscillation frequencies and durations of the oxic ( $\left.T_{\mathrm{OX}}\right)$ and anoxic $\left(T_{\mathrm{ANOX}}\right)$ periods (Fig. 5E-H). Generally, $T_{\mathrm{OX}}$ and $T_{\text {ANOX }}$ increased towards the burrow lumen and towards the surrounding anoxic sediment, respectively. The oscillation frequencies reached local maxima ( 1 to $1.5 \mathrm{~h}^{-1}$ ) in regions where both $T_{\mathrm{OX}}$ and $T_{\mathrm{ANOX}}$ were short (20 to $30 \mathrm{~min}$ ). The sediment type had no apparent effect on these temporal aspects of the oscillatory conditions (Fig. 6D-F). This was in contrast to the thickness of the oscillatory zone around the burrow lumen, which was restricted to a few millimeters in the $\mathrm{M}$ sediments but extended to several centimeters into the sediment surrounding the burrow in the MS and $\mathrm{S}$ sediments (Fig. 6D-F, J-L).

The oscillatory oxygen conditions were not restricted to the sediment surrounding the burrow but were also detected at the sediment-water interface (Fig. 6G-I). This was linked to the dynamic pressure gradients induced by the hydraulic activities of the shrimp and the resultant variable depths of oxygen penetration, with occasional rises of the oxic-anoxic boundary above the sediment surface (Fig. 4).

Oxygenation of the sediment surrounding the burrow varied asynchro- 

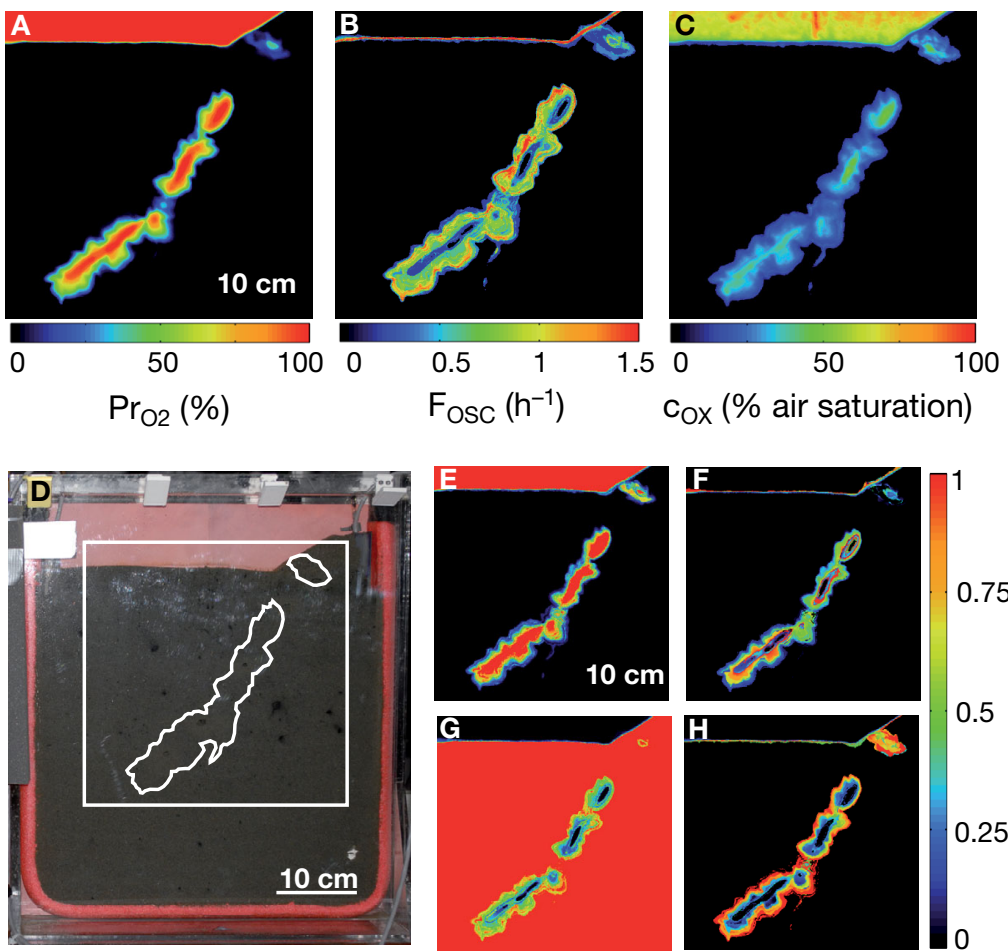

Fig. 5. Neotrypaea californiensis. Two-dimensional representation of spatiotemporal patterns in oxygen distributions induced by ghost shrimp over a $10 \mathrm{~h}$ period (individual MS1, permeability $k=10^{-11} \mathrm{~m}^{2}$ ). Shown are (A) oxygen probabilities $\left(\mathrm{Pr}_{\mathrm{O} 2}\right)$, (B) frequency of oxic-anoxic oscillations $\left(\mathrm{F}_{\mathrm{OSC}}\right),(\mathrm{C})$ average oxygen concentrations for the time when $\mathrm{O}_{2}$ was present $\left(\mathrm{C}_{\mathrm{OX}}\right)$, and average durations and standard deviations of $(\mathrm{E}, \mathrm{F})$ oxic and $(\mathrm{G}, \mathrm{H})$ anoxic periods $\left(\mathrm{T}_{\mathrm{OX}}\right.$ and $\left.\mathrm{T}_{\mathrm{ANOX}}\right)$. (D) The area where oxygen was detected at least once over the $10 \mathrm{~h}$ interval $\left(\right.$ size $\left.=125 \mathrm{~cm}^{2}\right)$

nously along the burrow (Video S4 in Supplement 2). This was due to the fact that the shrimp ventilated their burrows at different locales. Pleopod beating at different locations resulted in locale-specific pressure fields and sediment oxygenation (Supplement 2), and the spatial variations in the geochemical dynamics were directly related to the sequential activity in different parts of the complex burrow structures.

\section{DISCUSSION}

\section{Hydraulic activities of Neotrypaea californiensis}

The ghost shrimp Neotrypaea californiensis is a deposit-feeding thalassinid crustacean that inhabits a wide range of sandy sediments, does not line its burrow to a large extent, and continues to excavate below the surface in the search of food (Hornig et al.
1989). In the present study, we show that while feeding, burrowing, and ventilating its burrow, the shrimp induces porewater pressure fluctuations. Each type of activity is characterized by a specific porewater pressure waveform, and is performed in bouts of specific durations and frequencies and seen both in recordings in the laboratory (Fig. 2) and with unrestrained shrimp in the field (Fig. S3 in Supplement 1c at www. int-res.com/articles/suppl/m455p141 _supp.pdf). In terms of bout frequencies and pressure waveform magnitudes, the most important activities are burrow irrigation by pleopod beating and sediment blow-outs associated with burrow excavation. These activities have been described for other thalassinid shrimp (e.g. Stamhuis et al. 1996), but their frequencies and durations seem to be species specific. For example, Callianassa subterranea ventilates its burrow every $14 \mathrm{~min}$ for $1.3 \mathrm{~min}$, with approximately 60 pleopod beats per minute and instantaneous pumping rates of $10 \mathrm{ml}$ $\min ^{-1}$ (Stamhuis et al. 1996, Stamhuis \& Videler 1998). For $N$. californiensis we found more frequent and longer irrigation periods $\left(8.8\right.$ bouts $\mathrm{h}^{-1}$, each 2.4 min long; Table 2), as well as much lower pleopod beat frequencies $\left(22 \mathrm{~min}^{-1}\right)$, which were well within the range of values previously reported for this species (Torres et al. 1977).

The identified hydraulically effective shrimp activities did not differ much amongst the tested sediments, which was surprising given the large differences with respect to their permeability and reactivity (Table 1). A trend occurred of increasing time allocation to irrigation with a lower pleopod beat frequency in the sediments characterized by lower permeability and higher reactivity (Table 2), but given the low number of replicates and the high variance among the tested individuals the trend was not significant. The lack of differences may have been linked to the establishment of open burrow structures in low-permeability sediments (which lowered resistance to water flow through the burrows) and a possible reduction in reactivity in the burrow wall sediments due to a nearly continuous supply of dissolved oxygen. 

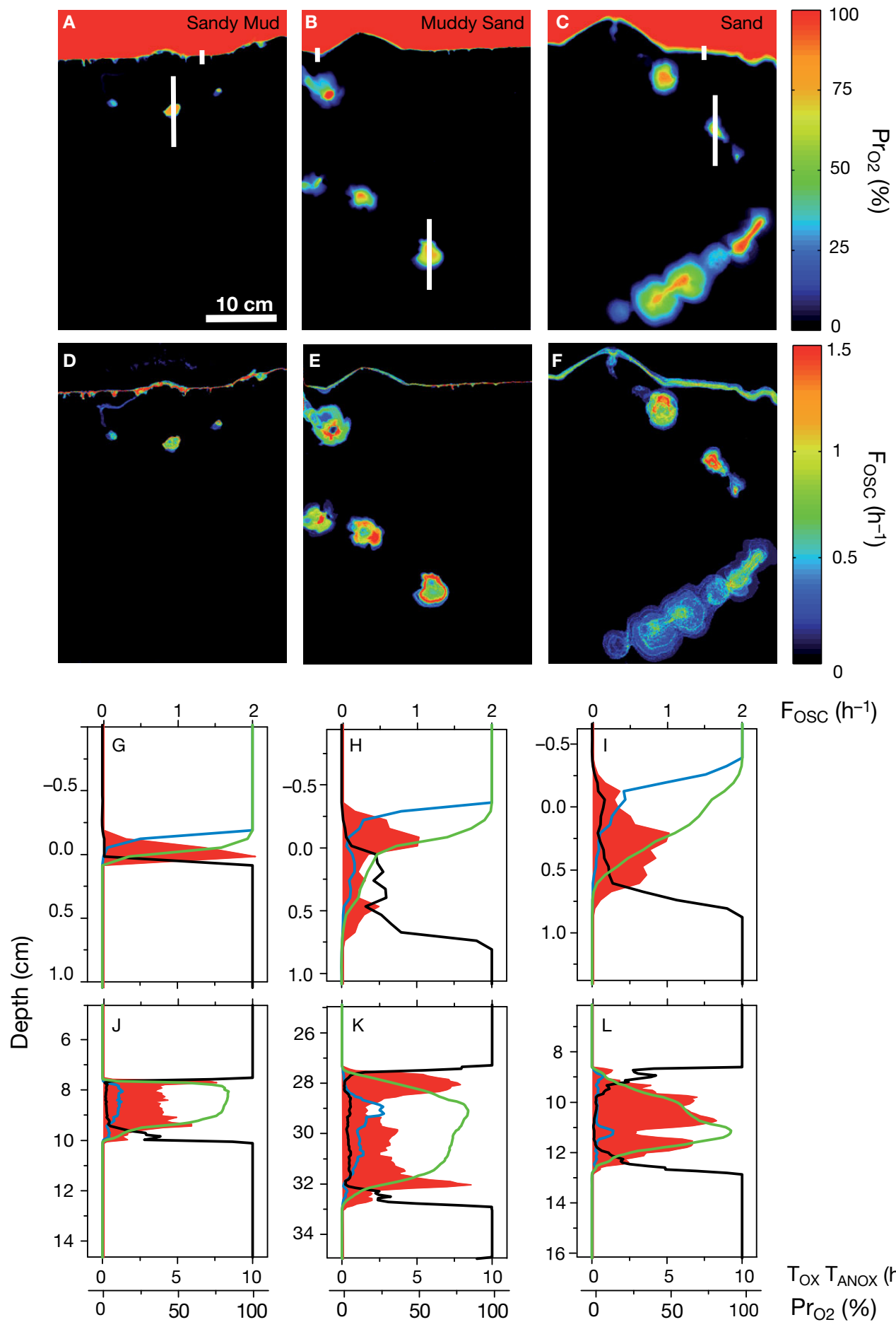

$\mathrm{F}_{\mathrm{OSC}}\left(\mathrm{h}^{-1}\right)$

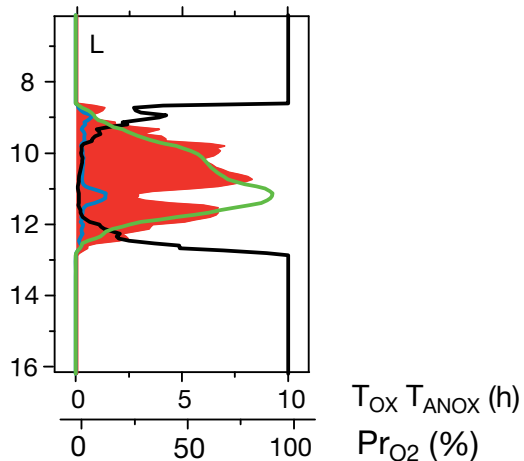

Fig. 6. Neotrypaea californiensis. Images of (A to C) oxygen probabilities $\left(\mathrm{Pr}_{\mathrm{O} 2}\right)$ and (D to $\mathrm{F}$ ) oxic-anoxic oscillation frequencies ( $F_{\mathrm{OSC}}$ ) induced by ghost shrimp in 3 sediment types (M3, MS3 \& S2, see Table 1) over 10 h of incubation. (G to L) Vertical profiles of the oscillatory parameters across the sediment-water interface (Panels G to I) and around the burrow (Panels J to L). The profile locations are indicated by white lines in the corresponding $\operatorname{Pr}_{\mathrm{O} 2}$ images. Oxygen probabilities (Pr $\mathrm{P}_{\mathrm{O}}$ green lines) and frequencies of oxic-anoxic oscillations ( $F_{\mathrm{OSC}}$ i red areas) represent the spatial means of 7 adjacent pixels (approximately $5 \mathrm{~mm}$ wide) perpendicular to the profiles, whereas durations of oxic ( $T_{\text {Ox }}$; blue lines) and anoxic ( $T_{\text {ANox; }}$ black lines) intervals represent temporal means of all oxic and anoxic periods in these pixels, respectively. The $y$-axis in Panels $\mathrm{G}$ to I is sediment depth, with 0 corresponding to the sediment surface. Oscillations above the sediment surface are the result of anoxic water pushed upwards during sediment pressurization 


\section{Hydraulic activity and porewater transport}

Hydraulic activities of infaunal organisms that live head down in blind-ending burrows, such as arenicolid polychaetes, drive substantial porewater advection and geochemical variability in sediments surrounding the burrows (Wethey \& Woodin 2005, Wethey et al. 2008, Volkenborn et al. 2010). In the present study, we show that similar phenomena occur also in more complex burrow structures, including those with $>1$ burrow opening.

Generally, the porewater pressure fluctuations associated with shrimp activities were detected throughout the entire sediment volume in the experimental tanks ( $\sim 6 \mathrm{l}$ of sediment), and resulted in a dynamic movement of the oxic-anoxic boundary in the sediment around the burrow, as well as at the sediment-water interface (Fig. 5). The extent of this movement increased with sediment permeability, and persisted even after the shrimp had established an open burrow system with a second opening.

Given the relatively large volume of sediment in the shrimp tanks with detectable pressure dynamics, we expect that bioadvective porewater transport in dense thalassinid beds is substantial. To estimate the magnitude of this phenomenon, we multiply the average irrigation activity of Neotrypaea californiensis found in the present study (20 pleopod beats $\min ^{-1}$, performed during $34 \%$ of the time) with the amount of water transported per pleopod beat. Since the latter quantity is not known for $N$. californiensis, we use the known value for Callianassa subterranea $(\sim 0.16 \mathrm{ml}$ per pleopod beat; Stamhuis et al. 1996, Stamhuis \& Videler 1998) and assume that it increases linearly with the thalassinid body size. C. subterranea individuals are $\sim 1.8$ times smaller than the individuals of $N$. californiensis used in the present study. Thus, the estimated volume of water pumped by $N$. californiensis per pleopod beat is $\sim 0.3 \mathrm{ml}$, which translates to an individual pumping rate of approximately $3 \mathrm{ld} \mathrm{d}^{-1}$. Assuming a shrimp density of 83 ind. $\mathrm{m}^{-2}$, which is at the lower end of densities found in the field (Dumbauld et al. 1996, DeWitt et al. 2004) and corresponds to the density of 1 shrimp tank ${ }^{-1}$ in our study, the estimated amount of water pumped daily by the shrimp is $250 \mathrm{l} \mathrm{m}^{-2}$, which is approximately the volume of porewater contained in the upper $50 \mathrm{~cm}$ of sediment. The widespread pressure dynamics and the movement of the oxic-anoxic boundaries documented in the present study indicate that a significant fraction of this water is transported across the burrow walls into and through the surrounding sediment by advection. Therefore, it seems realistic that in dense beds of $N$. californiensis most of the porewater in the top $50 \mathrm{~cm}$ of sediment is biohydraulically moved and exchanged in the course of a few days; this is similar to what has been concluded for dense beds inhabited by the lugworm Arenicola marina (Volkenborn et al. 2007, Wethey et al. 2008).

\section{Hydraulic activity and oxygenation of the burrow lumen}

Intermittent burrow irrigation by Neotrypaea californiensis was sufficient to maintain continuous oxygenation in at least parts of their burrows, with oxygen concentrations in the burrow water varying between 20 and $60 \%$ air saturation (Figs. $5 \& 6$ ). This is similar to observations reported for other thalassinids (Koike \& Mukai 1983, Forster \& Graf 1995). Thalassinids apparently initiate burrow ventilation (i.e. pleopod beating) when oxygen concentration in the burrow lumen falls below a minimum threshold (Farley \& Case 1968). This presumably drives the frequency of burrow irrigation and supports the metabolic activity of the shrimp (maximal metabolic activity occurs with $>10 \%$ air saturation; Thompson \& Pritchard 1969).

\section{Hydraulic activity and oxic-anoxic oscillations}

In contrast to the burrow lumen, which was partially oxygenated for extended periods by the shrimp's ventilation activity, sediment surrounding the shrimp burrows experienced frequent oscillations between oxic and anoxic conditions (Figs. 5 \& 6). Previous experimental studies on the role of redox oscillations for organic mineralization in sediments emphasized their importance on the timescale from hours to days (e.g. Aller 1994, Hulthe et al. 1998, Sun et al. 2002). This time-scale may indeed be relevant in the context of bioirrigation, e.g. in intertidal sediments due to oxygen depletion within burrows during low tides, or in submerged sediments due to diel variations in irrigation activity (Wenzhoefer \& Glud 2004). Here, we show that the time-scale on which oxic-anoxic oscillations occur in sediments due to hydraulic activities of benthic organisms is much shorter, in the range of minutes to hours. 
The spatial heterogeneity and temporal variability of geochemical conditions in the sediment are driven by (1) the behavior-specific porewater pressure waveforms, including positive and negative pressurization of the sediment (Fig. 2); (2) the intermittency of the hydraulic activity (Table 2); and (3) the changing location of the active organism within the burrow (Fig. S2 in Supplement 1b). While the relative durations of the oxic and anoxic periods, and thus the frequency of the oxic-anoxic oscillations, were a function of the durations and frequencies of shrimp activity, the thickness of the oscillatory layer depended primarily on the sediment type. In lowpermeability sediments the oscillatory zone extended only a few millimeters into the sediment surrounding the burrow, whereas in higher permeability sediments $\left(>10^{-11} \mathrm{~m}^{2}\right)$, which were also characterized by a considerably lower volume-specific oxygen demand, the zone was up to several centimeters thick (Figs. 5 \& 6). The latter observation suggests that in higher permeability sediments the volume of the oscillatory zone surrounding the burrow may easily be larger than the volume of the burrow itself.

Oxic-anoxic oscillations induced by shrimp activity were not limited to the sediment surrounding the burrow, but were also evident at the sediment surface. Here, the position of the oxic-anoxicboundary was pushed upwards during positive pressurization and downwards during negative pressurization (Fig. 4), similar to observations reported for the polychaetes Arenicola marina (Volkenborn et al. 2010) and Marenzelleria viridis (Kristensen et al. 2011, Quintana et al. 2011). In all sediment types the oscillations induced by shrimp activity occurred rather uniformly along the entire sediment surface, whereas in the muddy sediments localized oscillations due to the activity of small macrofauna and/or meifauna were additionally observed. This shows that small organisms also contribute significantly to oxygen dynamics in surficial sediments, as noted previously by Aller \& Aller (1992) and Glud \& Fenchel (1999).

\section{Oxic-anoxic oscillations and their ecological and biogeochemical implications}

Oscillations between oxic and anoxic conditions on the scale of minutes to hours associated with the hydraulic activities of benthic animals are likely to have a number of ecological and biogeochemical implications. With respect to ecology, we expect that the microbial community composition in sediments around burrows will vary in parallel with the prevail- ing character of the geochemical conditions, with microorganisms adapted to fluctuating conditions dominating the oscillatory zone and those adapted to relatively stable conditions dominating the burrow wall or the sediment volume beyond the oscillatory zone.

With respect to sediment biogeochemistry, we expect that oxic-anoxic oscillations will significantly enhance the efficiency and rate of organic mineralization, as suggested from the fact that degradation of organic material is often performed in multi-step reactions, with some of the steps favored by oxic conditions and others by anoxic conditions (Sun et al. 1993). The oscillations may also provide an explanation for the significant rates of $\mathrm{N}_{2}$ fixation by sulfate-reducing bacteria in sediments surrounding shrimp burrows (Bertics et al. 2010). $\mathrm{N}_{2}$ fixation is inhibited by oxygen and ammonia (Stewart 1969, Yoch \& Whiting 1986), and is therefore unlikely to occur in the burrow wall sediment, which is typically oxic if the burrow is continuously ventilated, or further away from the burrow, where ammonia concentrations are typically high. However, during a biohydraulically induced oxic-anoxic oscillation, when the possibly ammonia-rich porewater in the anoxic sediment is advectively replaced by oxygenated water and the delivered oxygen is subsequently consumed (e.g. by aerobic respiration), a temporal window with suitable conditions for $\mathrm{N}_{2}$ fixation may be created.

Another likely consequence of oxic-anoxic oscillations around intermittently ventilated burrows is the release of intermediates involved in metabolic pathways. This is suggested from the results of recent studies that investigated N-cycling under fluctuating conditions. For example, exposure of a complex microbial community with nitrifying and denitrifying activity to fluctuating concentrations of $\mathrm{O}_{2}$ and $\mathrm{NO}_{2}$ led, within seconds to minutes, to the release of intermediate gaseous species $\mathrm{NO}$ and $\mathrm{N}_{2} \mathrm{O}$ (Schreiber et al. 2009). Similarly, denitrifying bacteria ingested by filter- and deposit-feeding aquatic organisms emitted significant amounts of $\mathrm{N}_{2} \mathrm{O}$ due to the fact that the residence time of the bacteria in the anoxic gut (e.g. 2 to $3 \mathrm{~h}$ for Chironomus plumosus larvae) was insufficient to allow expression of the full set of genes required for complete denitrification (Stief et al. 2009). Therefore, by modifying chemical conditions in the sediment on the scale of minutes to hours, hydraulic activity of animals can disturb or interrupt microbial-mediated biogeochemical processes, which can lead to the release of intermediate chemical compounds. 


\section{Methodological considerations}

In a strict sense, the present study investigated behaviors of Neotrypaea californiensis and their geochemical impact during burrow establishment. Although on Days 3 and 4 of the incubation the shrimp had established burrows that resembled burrow morphologies previously documented for this species (Bertics \& Ziebis 2010, T. DeWitt unpubl. data), the complexity and size of the burrows would have likely increased further if the incubation times were prolonged to weeks or months. However, there was no apparent change in the irrigation behavior (duration and frequencies of irrigation bouts) during the course of the experiments. More importantly, porewater pressure dynamics measured in situ in an unmanipulated dense bed of $N$. californiensis in the field resembled closely the pressure waveforms detected in the experimental tanks (Supplement 3), and confirmed intermittent irrigation with very comparable irrigation bout durations $(2.4 \pm 2.1 \mathrm{~min}, \mathrm{n}=326$, with $90 \%$ of the bouts lasting $<5 \mathrm{~min}$ ). Given the lifestyle of near continuous exploration and excavation of $N$. californiensis (e.g. MacGintie 1934, Hornig et al. 1989, Dumbauld et al. 1996), the establishment of an entirely new burrow in our experiments may to some extent resemble the excavation of a new branch in the field. Thus, we feel confident that the frequencies and durations of hydraulic activities observed in our tank experiments are within the range of those characteristic for individuals under natural conditions.

In the present study, we used oxygen planar optodes to quantify oxic-anoxic oscillations on temporal and spatial scales relevant to infaunal bioirrigation behavior. Because the detection ability of this technique strongly depends on the distance between the burrow and the oxygen sensitive foil, and because the impermeable boundaries of the aquaria constrain porewater flow, the presented magnitudes and spatial extent of porewater pressure dynamics and oxygen dynamics may not accurately correspond to an unconstrained natural situation (Polerecky et al. 2006, Glud 2008, Volkenborn et al. 2010). However, because the close coupling between behaviors, pressure waveforms and oxygen dynamics in different parts of the burrow (e.g. Fig. 3 \& Fig. S2 in Supplement $1 \mathrm{~b}$ ) were repeatedly and consistently observed over several days and for several individual shrimp with various burrow morphologies, and because the pressure wave dynamics in the laboratory were consistent with those measured for field shrimp populations (Fig. S3 in Supplement 1c), we feel confident that our results provide a realistic description of the oscillatory character of geochemical conditions in and around thalassinid burrows.

\section{CONCLUSIONS}

Bioturbating infauna fundamentally alter microbial activity and associated biogeochemical processes in sediments, which can have far-reaching consequences for the functioning and overall character of an entire ecosystem (Welsh 2003). Using Neotrypaea californiensis as a model organism and oxygen as a reactive tracer, we demonstrate that sediments surrounding animal burrows, as well as surficial sediments, experience geochemical oscillations on the scale of minutes to hours due to intermittent bioirrigation activity. The sediment volume where such conditions prevail can become very large relative to the lumen of the burrow if the sediment is permeable (Fig. 6). Given the perfusing character of the bioadvective porewater transport, it is likely that oscillatory conditions are not limited to oxygen, but also occur for other dissolved constituents of sediments. Furthermore, they are not limited to sediments inhabited by $N$. californiensis, but are almost certainly associated with a wide range of hydraulically active animals, such as insect larvae, polychaetes, bivalves, and other crustaceans (e.g. Forster \& Graf 1995, Ziebis et al. 1996, Kristensen 2000, Polerecky et al. 2006, Timmermann et al. 2006, Woodin et al. 2010). We argue that to better understand the relationships between bioturbating infauna, microbial diversity, and biogeochemical processes, geochemical conditions in sediments need to be considered not only as highly heterogeneous in space but also as highly dynamic in time. Bioirrigation mimics that realistically imitate biohydraulically active animals ( $\mathrm{Na}$ et al. 2008, Matsui et al. 2011) together with the analytical approaches employed in the present study provide a useful set of tools for elucidating the role of this dynamism at multiple spatial and temporal scales.

Acknowledgements. Supported by NSF (OCE 0928002), the Office of Naval Research (N00014-0310352), NOAA (NA04NOS4780264), the Max Planck Society, and the US Environmental Protection Agency. We thank the staff at the Pacific Coastal Ecology Branch of EPA for logistical support. N.V., S.A.W., D.S.W., L.P., and T.H.D. contributed to the experimental design and writing, which was led by N.V. and L.P.; data collection was done by N.V., S.A.W., and D.S.W.; data analysis was led by N.V. and L.P.; L.P. wrote the optode data capture and redox oscillation analysis software; D.S.W. and S.A.W. built the pressure sensor system; D.S.W. and L.P. wrote the pressure/infaunal behavior analysis software. The original idea for the project stemmed from a conversation 
initiated by S.A.W. with T.H.D. We gratefully acknowledge comments on the manuscript given by Simon Thrush and Bob Ozretich, and 4 anonymous reviewers. The information in this document has been funded in part by the US Environmental Protection Agency. It has been subjected to review by the National Health and Environmental Effects Research Laboratory's Western Ecology Division and approved for publication. Approval does not signify that the contents reflect the views of the agency, nor does mention of trade names or commercial products constitute endorsement or recommendation for use.

\section{LITERATURE CITED}

Aller RC (1982) The effects of macrobenthos on chemical properties of marine sediment and overlying water. In. McCall PL, Tevesz MJS (eds) Animal-sediment relations. Plenum Press, New York, NY

Aller RC (1988) Benthic fauna and biogeochemical processes in marine sediments: the role of burrow structures. In: Blackburn TH, Sørensen J (eds) Nitrogen cycling in coastal marine environments. John Wiley, New York, NY

Aller RC (1994) Bioturbation and remineralization of sedimentary organic matter: effects of redox oscillation. Chem Geol 114:331-345

Aller RC, Aller JY (1992) Meiofauna and solute transport in marine muds. Limnol Oceanogr 37:1018-1033

Astall CM, Taylor AC, Atkinson RJA (1997) Behavioural and physiological implication of a burrow-dwelling lifestyle for two species of upogebiid mud-shrimp (Crustacea: Thalassinidea). Estuar Coast Shelf Sci 44:155-168

Atkinson RJA, Taylor AC (2005) Aspects of the physiology, biology and ecology of thalassinidean shrimps in relation to their burrow environment. Oceanogr Mar Biol Annu Rev 43:173-210

Bertics VJ, Ziebis W (2009) Biodiversity of benthic microbial communities in bioturbated coastal sediments is controlled by geochemical microniches. ISME J 3:1269-1285

Bertics VJ, Ziebis W (2010) Bioturbation and the role of microniches for sulfate reduction in coastal marine sediments. Environ Microbiol 12:3022-3034

- Bertics VJ, Sohm JA, Treude T, Chow CE, Capone DG, Fuhrman JA, Ziebis W (2010) Burrowing deeper into benthic nitrogen cycling: the impact of bioturbation on nitrogen fixation coupled to sulfate reduction. Mar Ecol Prog Ser 409:1-15

> Coelho VR, Cooper RA, Rodrigues SA (2000) Burrow morphology and behavior of the mud shrimp Upogebia omissa (Decapoda: Thalassinidea: Upogebiidae). Mar Ecol Prog Ser 200:229-240

Cravo-Laureau C , Hernadez-Raquet G, Vitte I, Jézéquel R and others (2011) Role of environmental fluctuations and microbial diversity in degradation of hydrocarbons in contaminated sludge. Res Microbiol 162:888-895

$>$ D'Andrea AF, DeWitt TH (2009) Geochemical ecosystem engineering by the mud shrimp Upogebia pugettensis (Crustacea: Thalassinidae) in Yaquina Bay, Oregon: density-dependent effects on organic matter remineralization and nutrient cycling. Limnol Oceanogr 54:1911-1932

DeWitt TH, D'Andrea AF, Brown CA, Griffen BD, Eldridge PM (2004) Impact of burrowing shrimp populations on nitrogen cycling and water quality in western North American temperate estuaries. In: Tamaki A (ed) Proc Symp Ecology of Large Bioturbators in Tidal Flats and
Shallow Sublittoral Sediments - from individual behavior to their role as ecosystem engineers. 1-2 Nov 2003, Nagasaki. University of Nagasaki, Nagasaki, p 107-118

> Dumbauld BR, Armstrong DA, Feldman KL (1996) Lifehistory characteristics of two sympatric thalassinidean shrimps, Neotrypaea californiensis and Upogebia pugettensis, with implications for oyster culture. J Crustac Biol 16:689-708

> Dworschak PC (1981) The pumping rates of the burrowing shrimp Upogebia pusilla (Petagna) (Decapoda: Thalassinidea). J Exp Mar Biol Ecol 52:25-35

> Farley RD, Case JF (1968) Perception of external oxygen by the burrowing shrimp, Callianassa californiensis Dana and C. affinis Dana. Biol Bull 134:261-265

Forster S, Graf G (1995) Impact of irrigation on oxygen flux into the sediment: intermittent pumping by Callianassa subterranea and, piston-pumping, by Lanice conchilega. Mar Biol 123:335-346

Foster-Smith RL (1978) An analysis of water flow in tubeliving animals. J Exp Mar Biol Ecol 34:73-95

Glud RN (2008) Oxygen dynamics in marine sediments. Mar Biol Res 4:243-289

> Glud RN, Fenchel T (1999) The importance of ciliates for interstitial solute transport in benthic communities. Mar Ecol Prog Ser 186:87-93

Griffis RB, Chavez FL (1988) Effects of sediment type on burrows of Callianassa californiensis Dana and C. gigas Dana. J Exp Mar Biol Ecol 117:239-253

Griffis RB, Suchanek TH (1991) A model of burrow architecture and trophic modes in thalassinidean shrimp (Decapoda: Thalassinidea). Mar Ecol Prog Ser 79:171-183

Hornig S, Sterling A, Smith SD (1989) Species profiles: life histories and environmental requirements of coastal fishes and invertebrates (Pacific Northwest)-Ghost shrimp and blue mud shrimp. US Fish Wildlife Service Biological Report 82 (11.93), US Army Corps of Engineers, TR EL-82-4, Washington, DC

> Huettel M, Ziebis W, Forster S (1996) Flow-induced uptake of particulate matter in permeable sediments. Limnol Oceanogr 41:309-322

Hulthe G, Hulth S, Hall POJ (1998) Effect of oxygen on degradation rate of refractory and labile organic matter in continental margin sediments. Geochim Cosmochim Acta 62:1319-1328

Klute A, Dirksen C (1986) Hydraulic conductivity and diffusivity: laboratory methods. In: Klute A (ed) Methods of soil analysis, Part 1, physical and mineralogical methods. American Society of Agronomy, Madison, WI, p 687-700

Koike I, Mukai H (1983) Oxygen and inorganic nitrogen contents and fluxes in burrows of the shrimps Callianassa japonica and Upogebia major. Mar Ecol Prog Ser 12:185-190

Kristensen E (2000) Organic matter diagenesis at the oxic/ anoxic interface in coastal marine sediments, with emphasis on the role of burrowing animals. Hydrobiologia 426:1-24

Kristensen E (2001) Impact of polychaetes (Nereis spp. and Arenicola marina) on carbon biogeochemistry in coastal marine sediments. Geochem Trans 2:92-103

Kristensen E, Kostka JE (2005) Macrofaunal burrows and irrigation in marine sediment: microbiological and biogeochemical interactions. In: Kristensen E, Kostka JE, Haese R (eds) Interactions between macro- and microorganisms in marine sediments. American Geophysical Union, Washington, DC, 125-157 
Kristensen E, Hansen T, Delefosse M, Banta GT, Quintana CO (2011) Contrasting effects of the polychaetes Marenzelleria viridis and Nereis diversicolor on benthic metabolism and solute transport in sandy coastal sediment. Mar Ecol Prog Ser 425:125-139

Laverock B, Smith CJ, Tait K, Osborn AM, Widdicombe S, Gilbert JA (2010) Bioturbating shrimp alter the structure and diversity of bacterial communities in coastal marine sediments. ISME J 4:1531-1544

Laverock B, Gilbert JA, Tait K, Osborn AM, Widdicombe S (2011) Bioturbation: impact on the marine nitrogen cycle. Biochem Soc Trans 39:315-320

MacGinitie GE (1934) The natural history of Callianassa californiensis Dana. Am Midl Nat 15:166-177

> Matsui GY, Volkenborn N, Polerecky L, Henne U, Wethey DS, Lovell CR, Woodin SA (2011) Mechanical imitation of bidirectional bioadvection in aquatic sediments. Limnol Oceanogr Methods 9:84-96

> Mermillod-Blondin F, Rosenberg R (2006) Ecosystem engineering: the impact of bioturbation on biogeochemical processes in marine and freshwater benthic habitats. Aquat Sci 68:434-442

> Meysman FJR, Galaktionov OS, Middelburg JJ (2005) Irrigation patterns in permeable sediments induced by burrow ventilation: a case study of Arenicola marina. Mar Ecol Prog Ser 303:195-212

> Na T, Gribsholt B, Galaktionov OS, Lee T, Meysman FJR (2008) Influence of advective bio-irrigation on carbon and nitrogen cycling in sandy sediments. J Mar Res 66: 691-722

Papaspyrou S, Gregersen T, Cox RP, Thessalou-Legaki M, Kristensen E (2005) Sediment properties and bacterial community in burrows of the ghost shrimp Pestarella tyrrhena (Decapoda: Thalassinidea). Aquat Microb Ecol 38:181-190

Pillay D, Branch GM (2011) Bioengineering effects of burrowing thalassinidean shrimps on marine soft-bottom ecosystems. Oceanogr Mar Biol Annu Rev 49:137-192

Polerecky L, Franke U, Werner U, Grunwald B, De Beer D (2005) High spatial resolution measurement of oxygen consumption rates in permeable sediments. Limnol Oceanogr Methods 3:75-85

> Polerecky L, Volkenborn N, Stief P (2006) High temporal resolution oxygen imaging in bioirrigated sediments. Environ Sci Technol 40:5763-5769

> Posey MH (1986) Changes in a benthic community associated with dense beds of a burrowing deposit feeder, Callianassa californiensis. Mar Ecol Prog Ser 31:15-22

Precht E, Franke U, Polerecky L, Huettel M (2004) Oxygen dynamics in permeable sediments with wave-driven pore water exchange. Limnol Oceanogr 49:693-705

Quintana CO, Hansen T, Delefosse M, Banta G, Kristensen E (2011) Burrow ventilation and associated porewater irrigation by the polychaete Marenzelleria viridis. J Exp Mar Biol Ecol 397:179-187

> Riisgård HU, Larsen PS (2005) Water pumping and analysis of flow in burrowing zoobenthos - an overview. Aquat Ecol 39:237-258

Rowden AA, Jones MB (1995) The burrow structure of the mud-shrimp Callianassa subterranea (Decapoda: Thalassinidea) from the North Sea. J Nat Hist 29: 1155-1165

Schreiber F, Loeffler B, Polerecky L, Kuypers MMM, De Beer D (2009) Mechanisms of transient nitric oxide and nitrous oxide production in a complex biofilm. ISME J 3:
1301-1313

Stamhuis EJ, Videler JJ (1998) Burrow ventilation in the tube-dwelling shrimp Callianassa subterranea (Decapoda: Thalassinidea). J Exp Biol 201:2159-2170

> Stamhuis EJ, Dekker T, van Etten Y, Videler JJ (1996) Behaviour and time allocation of the burrowing shrimp Callianassa subterranea (Decapoda, Thalassinidea). J Exp Mar Biol Ecol 204:225-239

> Stewart WDP (1969) Biological and ecological aspects of nitrogen fixation by free-living micro-organisms. Proc R Soc Lond B Biol Sci 172:367-388

> Stief P, Poulsen M, Nielsen LP, Brix H, Schramm A (2009) Nitrous oxide emission by aquatic macrofauna. Proc Natl Acad Sci USA 106:4296-4300

Sun MY, Lee C, Aller RC (1993) Laboratory studies of oxic and anoxic degradation of chlorophyll-a in Long Island Sound sediments. Geochim Cosmochim Acta 57:147-157

- Sun MY, Aller RC, Lee C, Wakeham SG (2002) Effects of oxygen and redox oscillation on degradation of cellassociated lipids in surficial marine sediments. Geochim Cosmochim Acta 66:2003-2012

> Thompson RK, Pritchard AW (1969) Respiratory adaptations of two burrowing crustaceans, Callianassa californiensis and Upogebia pugettensis (Decapoda, Thalassinidea). Biol Bull 136:274-287

Timmermann K, Banta GT, Glud RN (2006) Linking Arenicola marina irrigation behaviour to oxygen transport and dynamics in sandy sediments. J Mar Res 64:915-938

Torres JJ, Gluck DL, Childress JJ (1977) Activity and physiological significance of the pleopods in the respiration of Callianassa californiensis (Dana) (Crustacea: Thalassinidea). Biol Bull 152:134-146

> Volkenborn N, Polerecky L, Hedtkamp SIC, van Beusekom JEE, de Beer D (2007) Bioturbation and bioirrigation extend the open exchange regions in permeable sediments. Limnol Oceanogr 52:1898-1909

Volkenborn N, Polerecky L, Wethey DS, Woodin SA (2010) Oscillatory porewater bioadvection in marine sediments induced by hydraulic activities of Arenicola marina. Limnol Oceanogr 55:1231-1247

Welsh DT (2003) It's a dirty job but someone has to do it: the role of marine benthic macrofauna in organic matter turnover and nutrient recycling to the water column. Chem Ecol 19:321-342

> Wenzhöfer F, Glud RN (2004) Small-scale spatial and temporal variability in benthic $\mathrm{O}_{2}$ dynamics of coastal sediments: impact of fauna activity. Limnol Oceanogr 49: 1471-1481

Wethey DS, Woodin SA (2005) Infaunal hydraulics generate porewater pressure signals. Biol Bull 209:139-145

- Wethey DS, Woodin SA, Volkenborn N, Reise K (2008) Porewater advection by hydraulic activities of lugworms, Arenicola marina: a field, laboratory and modeling study. J Mar Res 66:255-273

> Woodin SA, Wethey DS, Volkenborn N (2010) Infaunal hydraulic ecosystem engineers: cast of characters and impacts. Integr Comp Biol 50:176-187

> Yoch DC, Whiting GJ (1986) Evidence for $\mathrm{NH}_{4}{ }^{+}$switch-off regulation of nitrogenase activity by bacteria in salt marsh sediments and roots of the grass Spartina alterniflora. Appl Environ Microbiol 51:143-149

Ziebis W, Forster S, Huettel M, Jørgensen BB (1996) Complex burrows of the mud shrimp Callianassa truncata and their geochemical impact in the sea bed. Nature 382: $619-622$ 